\title{
The effect of an enrichment unit on climate change awareness and basic science process skills among gifted female primary school students
}

Fatema Saeed Sanad ${ }^{1}$, Dr. Fatima Ahmed Aljasim ${ }^{2}$

Dr. Huda Soud AlHendal ${ }^{3}$

1,2,3 Arabian Gulf University, Manama, Bahrain

3 dr.hudash.h@gmail.com 


\title{
The effect of an enrichment unit on climate change awareness and basic science process skills among gifted female primary school students
}

\author{
Fatema Saeed Sanad ${ }^{1}$, Dr. Fatima Ahmed Aljasim ${ }^{2}$ \\ Dr. Huda Soud AlHendal ${ }^{*}$ \\ 1,2,3 Arabian Gulf University, Manama, Bahrain \\ 3 dr.hudash.h@gmail.com
}

\begin{abstract}
Received: 7-9-2021
Revised: 16-9-2021

Accepted: 25-9-2021

DOI: https://doi.org/10.31559/CCSE2021.3.1.3

\section{Abstract:}

This study investigated how introducing climate change-themed lessons into the curriculum of gifted primary school females in Bahrain affected Climate Change Awareness and Basic Science Process Skills. Students included Students included 40 gifted sixth grade females divided into two groups: a 20-student experimental group and a 20-student control group. Basic Science Process Skills Activities and Climate Change Awareness Scale were used as the pre- and post-test to measure the science skills and climate change awareness among both groups. The experimental group received the enrichment unit. The Mann-Whitney \& Wilcoxon tests showed that Significant differences emerged between experimental and control groups on the climate change awareness scale, but not in the behavioral domain of the scale. Possible explanations are included.
\end{abstract}

Keywords: Climate Change Awareness; Gifted Female; Basic Science Process Skills.

\footnotetext{
* Corresponding author

Huda Soud AlHendal

Arabian Gulf University, Manama, Bahrain

E-mail: dr.hudash.h@gmail.com
} 


\section{Introduction}

Learning in today's classrooms should not be disconnected from gifted students' real-world experiences (Akinoglu \& Tandogan, 2007). Providing the opportunity for gifted students to address real-world problems may create avenues for them to engage in their communities while developing academic skills and knowledge. Climate Change as a topic is one of the problems that could be addressed for gifted learners to stimulate their thinking, provide them with the challenge they need, and prepare them to become productive people in their communities in the future. Additionally, these science topics might help to develop students' scientific thinking and science process skills. This study aimed to determine the effect of providing an enriched curriculum on climate change awareness and basic science process skills among Bahraini gifted female primary school students.

\section{Objectives of the Study:}

1. To assess the effectiveness of applying an enrichment unit on gifted students' climate change awareness.

2. To assess the effectiveness of applying an enrichment unit on the development of gifted students' basic skills (observation, communication, measurement, and classification).

\section{Giftedness in Bahrain:}

In 1996, the Ministry of Education in the Kingdom of Bahrain established programs for gifted children in government schools (Aljasim, 2001). The Ministry selected teachers from different subjects based on a range of criteria - such as having the Excellence degree in teaching and teaching one of the primary subject (Mathematics, English, Science, or Arabic) - and the chosen teachers were provided with scholarships to get their master's degree in gifted education from the
Arabian Gulf University. They were then employed as gifted specialists in schools, where they helped identify the gifted students, supported those students, provided them with the programs that meet their needs, and communicated knowledge and experiences about gifted education to other teachers in the school (Aljasim, 2001).

The Ministry of Education in the Kingdom of Bahrain adopted a definition of giftedness that combines the U.S. Office of Education definition (U.S. Department of Education, 1993) and Renzulli's (2005) definition of gifted behavior, which states,

Gifted behavior consists of thought and action resulting in an interaction among three basic clusters of human traits, above average general/ or specific abilities, high levels of task commitment, and high levels of creativity in one or more kinds of giftedness: (a) intellectual giftedness, (b) creative giftedness, (c) specific academic giftedness, (d) leadership giftedness, (e) performing and visual arts giftedness. (Ministry of Education in Bahrain, 2012, p.2)

In Bahrain's government schools, the gifted specialist is responsible for identifying academically gifted students. Students must meet the following criteria to be considered gifted:

1. Achieving a grade of $90 \%$ or above in all academic subjects.

2. Receiving a teacher's nomination, which is based on the Behavior Characteristics of Superior Students' scale (motivation and leadership domains) (Renzulli et al., 2002).

3. Attaining a high score on the Screaming Assessment for Gifted Elementary Students - (SAGES-2) (Johnson \& Corn, 2001).

4. Attaining a high score on the Creativity Assessment Packet (Williams, 1980). 
After evaluating and averaging the scores mentioned above, the gifted specialist selects the highest 3\%-5\% of scores from across the school.

Gifted students in government schools attend enrichment programs that emphasize creative problem solving, idea exchange, research, and independent learning, in addition to receiving counseling sessions that feature topics such as self-esteem, self-efficacy, and emotional intelligence. Gifted students attend these sessions during the school day (Ministry of Education in Bahrain, 2012).

Enrichment for Gifted Students

Gifted students have different needs that cannot be met through strategies that apply to the mainstream student population. If the needs of gifted students have not been met, academic, social, and emotional problems may arise (Bainbridge, 2018). VanTassel-Baska (1994) notes that teaching gifted students should be different than teaching other students regarding the rate, speed, and complexity of teaching.

Clark (2007) defines enrichment as the various in-depth experiences in topics or activities that exceeds what is given in the regular curriculum. Jarwan (2002) indicates that the term "enrichment" refers to the changes and additions to the content of curricula, teaching methods, or learning outcomes without reducing the duration of an academic year or transitioning a student to a higher class. Smith et al. (2004) also define enrichment as a set of experiences that are added to the regular curriculum to challenge the abilities of gifted students and provide them with deeper learning opportunities, such as Al Madinah world Program based by Abdeen 2015, it aims to develop concurrent thinking and accelerate creativity, which contains three strategies: synchronization strategy, exploitation strategy, and creative acceleration strategy (abdeen,2014; Abdeen\& Ewies, 2019). Enrichment includes modification or additions to the prescribed curriculum, for instance, introducing subjects that are not offered to general education students, increasing the difficulty of traditional subjects without shortening the time required to skip a course of study, or exploring one or more subjects in more depth (Clark, 2007). Rakow (2011) points out that one of the goals of gifted enrichment programs is creating links between gifted students and the communities in which they live.

Gifted students are characterized by their sense of responsibility and interest in global issues (Rimm, Siegle, \& Davis, 2017). Addressing these real-life problems through enrichment programs prepares gifted students for the future and turns them from passive recipients of information to active learners and problem solvers (Akinoglu \& Tandogan, 2007). Climate Change is a crucial issue that could be posed in gifted students' enrichment programs, as it gives them the opportunity to create alternative discourses to change the present and shape the future.

\section{Climate Change Education:}

The Earth has already experienced irrevocable changes because of humanmade emissions of greenhouse gases. Increasing temperatures, extreme weather swings, droughts, wildfires, storms, flooding, sea-level rise, acidic oceans, and extinction of many animal and plant species are all results of climate change (Beach, Share, \& Webb, 2017). Furthermore, changes in the Earth's climate will likely have health and socioeconomic consequences that impact individuals and societies (Intergovernmental Panel on Climate Change, 2014).

Since our planet has warmed one degree Celsius more rapidly than any time in Earth's history in 2016 (Beach, Share, \& Webb, 2017), recent research indicates that global temperatures may increase by 4 degrees Celsius by as early as the 2070s and 
perhaps even sooner (Intergovernmental Panel on Climate Change, 2013). At the 2015 United Nations Climate Change Conference in Paris, there was a sense of urgency among the 169 nations that attended. By that time, scientists had confirmed that we have only 25-30 years left to dramatically lower emission in order to keep global warming to more than 2 degrees Celsius. The Kingdom of Bahrain was one the countries that signed onto the conference (Intergovernmental Panel on Climate Change, 2016).

As climate change presents a serious threat to life on earth, it is paramount that teachers and students become knowledgeable about climate change, spread awareness, and advocate for laws and policies that will reduce greenhouse gases (Shepardson, Roychoudhury, \& Hirsch, 2017). According to the Next Generation Science Standards (NGCS), climate change education should be explicitly integrated in $\mathrm{K}-12$ science education (Hestness, McDonald, Breslyn, McGinnis, \& Mouza, 2014). Gifted students need to be nurtured as informed citizens who participate in decision making regarding a collective future: "Education is an essential element of the global response to climate change. It helps young people understand and address the impact of global warming, encourages changes in their attitudes and behavior and helps them adapt to climate change-related trends" (UNESCO, 2013)

Beach, Share, \& Webb (2017) offer strategies to integrate climate change topics in school curricula; For instance, Cli-fi imagination "Climate Fiction" which is a new kind of literature that portrays the human experience of coping with climate change. Cli-fi fosters gifted students' imagination about possible future effects of climate change. Cli-Fi has been called the "hottest new literary genre" (Stankorb,
2016). Students can create many products using Cli-fi, such as picture books, poetry, Cli-Fi short stories, Cli-Fi novels, and CliFi films (Beach, Share, \& Webb ,2017). Moreover, writing about climate change is a kind of writing can be divided into placebased writing, creative writing, and persuasive writing. Before students start writing, they should have sufficient knowledge to write. Students can pose questions, research, and read deeply before starting to write (Hestness, et al, 2014). Another strategy that could help in climate teaching is Critical media/ digital analyses of climate change, whereas students spend most of their time using various forms of media (Rideout, Luricella, \& Wartella, 2011), media messages regarding climate change issues are an ideal space for gifted students to critically analyze the media's use of assumptions, actions, and inactions. Using a framework of critical media literacy, educators can guide students to create their own media messages about environmental justice and sustainability. According to a report by the National Environmental Education and Training Foundation (2005), "children get more environmental information (83\%) from the media than from any other source" (Coyle, 2005, p. x). Furthermore, Using Drama and Gaming to address climate change provide a "living through experience" (Pirie, 1997, p.52), assuming roles addressing problems or dilemmas, responding to others, or inventing imagined spaces in dialogic, open-ended ways. Drama offers a valuable way to involve students in the "social drama" of conflicts and social debates about climate change (Smith \& Howe, 2015). As with the drama activities, games allow players to go beyond simply learning about climate change to actively engage in missions or projects involving decision-making process (Wu \& Lee, 2015). Interdisciplinary teaching about climate change is another useful strategy to employ in elementary 
schools. For instance, in combining ELA and social studies with science, students can address such justice issues as how people who generate the least emissions are impacted more than the people who generate the most emissions (Turner, 2015). Addressing climate change issues in different subjects helps to develop a firm knowledge basis regarding climate change topics among young learners. This can increase gifted students' responsibility toward the Earth and improve their global awareness and scientific process skills.

\section{Science Process Skills:}

Science process skills are usually identified as the skills or abilities necessary to the process of scientific discovery (Maranan, 2017), and they include procedural skills, experimental skills, and science habits of mind or scientific inquiry abilities (Harlen, 1999). According to Padilla (1990), these skills are defined as a set of broadly transferable abilities appropriate to many science disciplines and reflective of the behavior of scientists. Karamustafaoglu (2011) states that science process skills are the thinking skills that we use to get information. Aydogdu (2015) classifies science process skills into two categories: basic and integrated process skills. The necessary process skills include observing, communicating, inferring, measuring, classifying, predicting, using time-space relationships, and using numbers. Integrated process skills include identifying and defining variables, interpreting data, manipulating materials, recording data, formulating hypotheses, designing investigations, and making inferences and generalizations (Zeidan \& Jayosi, 2015). According to Skamp (1988) and Padilla (1990), basic science process skills are simple and easy to acquire; they are the foundation for the acquisition of integrated science process skills. Therefore, this paper focuses on developing gifted students' acquisition of four basic skills: observation, communication, measurement, and classification. Coronado (2016) points out that science process skills should not be presented as a separate stand-alone lesson. These skills need to be integrated with essential concepts.

Science process skills are necessary tools to produce and use scientific information, perform scientific research, and solve problems (Aktamis \& Ergin, 2008). According to the Next Generation Science Standards (NRC, 2013), helping students engage in scientific inquiry and develop science inquiry skills in the context of learning science is one of the most important goals of science education. Panoy (2013) asserts that the goal of science education is to develop students' skills and enable individuals to apply those skills in their everyday lives.

Rillero (1998) emphasizes that individuals who cannot use science process skills will have difficulty succeeding in daily life, as the development of science process skills enables students to gain the skills necessary to solve everyday problems. Harlen (1999) reported that the acquisition of the science process skills is significant for students, and those students who cannot sufficiently acquire these skills also cannot comprehend the world or make necessary connections (Aydogdu, 2015). Thus, educators need to develop their students' science process skills, content knowledge, and questioning skills, all of which are important parts of a primary school science education (Miles, 2010).

\section{Research Questions:}

1. Is offering a climate change-themed enrichment unit to 6th grade female gifted students affects their climate change awareness?

2. Is offering a climate change-themed enrichment unit to 6th grade female gifted students affects their 
International Journal of Childhood, Counselling, \& Special Education (CCSE), Volume3, Issue1, Sept: 2021, pp.32-46

development of basic science process skills (observation, communication, measurement, and classification)?

\section{Rationale:}

As mentioned earlier, gifted students have talents and abilities not cultivated in a general education classroom. Characteristics such as high intellectual abilities, sensitivity to environmental issues, global awareness, and scientific curiosity require special education that meets their needs. Gifted students' education should include depth, complexity, scientific skills, and additional intellectual challenges. Climate change may already be of concern to gifted students and addressing this topic can help to create informed and effective citizens who contribute to reducing greenhouse gases. Though many studies have considered climate change awareness among adults (Harker-Schuch \& BuggeHenriksen, 2013; Wachholz, Artz, \& Chene, 2014), there are none focused on gifted students. It is important to spread climate change awareness among gifted students, especially from an early age, as these students have great potential to make discoveries that could save the Earth. This study emphasizes the importance of teaching global issues to gifted learners and examines the effects of this kind of curricular intervention on their civic awareness and basic science process skills. Thus, we sought to prove the following hypotheses:

1. Offering a climate change-themed enrichment unit to 6th grade female gifted students affects their climate change awareness.

2. Offering a climate change-themed enrichment unit to 6th grade female gifted students affects their development of basic science process skills (observation, communication, measurement, and classification).

\section{Methods}

\section{Participants:}

The participants for this study were selected from two primary public schools in Bahrain. All participants had high scores in cognitive tests, strong academic records, and recommendations from their teachers. The participants in both schools were enrolled in gifted education programs. The final sample of students included 40 students in Grade 6, with 20 students in the experimental group and 20 students in the control group.

\section{Measures:}

The Climate Change Awareness Scale (CCAS) was prepared by the researchers to assess the students' awareness of the topic addressed. The scale contained 30 items that were divided into 3 domains (cognitive, emotional, and behavioral). Students were asked to respond using a 3point scale (yes, no, don't know for the cognitive and emotional domains; strongly agree, agree, disagree for the behavioral domain). The items were independently evaluated for clarity, suitability of language, and relevance to intended constructs by three experts in gifted education and two experts in geographic and environmental information systems. Wording changes were made in response to the evaluators' feedback. Items on all measures were worded in the positive, except for six questions. The scale was administrated on a sample of 100 female fifth grade students to compute and test its reliability and construct validity. Reliability coefficient of the scale (Cronbach's Alpha) was calculated and found to be around 0.77 which meant that the scale was appropriate to be used and showed that all items were correlated to the domains they measure and related to the whole scale i.e. (all computed internal reliability coefficients were found to be having a threshold or cut-off as an 
International Journal of Childhood, Counselling, \& Special Education (CCSE), Volume3, Issue1, Sept: 2021, pp.32-46

acceptable, sufficient, or satisfactory level (a $\geq 0.58$ ) for all items)).

Additionally, the Basic Science Process Skills Activities (BSPSA) was used to assess four basic science skills (observation, communication, classification, and measurement). These activities were originally developed by Ostlund and Mercier (2012) and then translated to Arabic and modified to reflect Arabic culture by Almaymooni (2014). The activities had adequate psychometric properties, and they were used in their original form or adapted as appropriate for the present study.

The researchers designed a Climate Change Enrichment Unit. The unit was composed of 22 lessons that highlighted the issue of climate change, touching on its causes, effects, and possible solutions. The lessons were designed in three stages based on Aljughaiman's (2017) Oasis Enrichment Model: 1) discovering the problem, 2) perfecting the solution and 3) production and creation. During the unit, students experienced some kinesthetic activities and some activities that encouraged discussion, analysis, inquiry, deductive thinking, research, and experimentation. By the end of the unit, each student (either individually or as part of a group) was required to come up with a creative product that could be a solution to the problem. At the last session, students presented their creative products in a gallery exhibition held in the school's auditorium, explaining to teachers, parents, administrators, and friends how they had come to these solutions and what costs would be associated with implementing their ideas. The unit was evaluated by six experts in science education and gifted education for suitability of activities for intended sample and relevance to their goals. Changes in their projects were made in response to the evaluators' feedback.

\section{Procedures:}

For both groups, CCAS and BSPSA were administered to the participants as pretests in their gifted classes in consultation with the gifted specialist at each school. The researcher began by explaining the purpose and the importance of the gifted students' participation in this study. Also, the researcher assured the participant of the confidentiality of their responses and that their responses would be used only for research purposes. The instructions were given before distributing the surveys, and the researcher asked the participants whether they had any question before completing them. The participants were given 25-30 minutes to complete the scale and an hour to complete the science process skills activities. The equivalency of the pretest scores on CCAS and BSPSA between the groups was examined (Tables $1 \&$ 2). The participants in the experimental group attended the enrichment unit over a 5 -week period (4 periods per week).

After completing the enrichment unit, the participants in both groups completed the standardized measures again as posttests, and their responses were entered into a computer-based system for statistical analysis so that the data could be analyzed using an SPSS package.

\section{Results}

To verify the hypothesis of the study, the pretest and posttest scores on the CCAS and BSPSA of the students in the experimental and control groups were compared. First, a Mann-Whitney U test was used to examine the equivalency of the pretest scores on CCAS between the experimental and control group (Table 1). As indicated in Table 1, the pretest scores on the CCAS showed no statistical differences between the control and experimental groups ( $p>0.05)$. 
International Journal of Childhood, Counselling, \& Special Education (CCSE), Volume3, Issue1, Sept: 2021, pp.32-46

Table (1): Results of Mann-Whitney U test to compare the groups' pretest scores on CCAS

\begin{tabular}{|c|c|c|c|c|c|c|}
\hline & & $\mathrm{N}$ & Mean Rank & Sum of Ranks & $Z$ & $\mathrm{P}$ \\
\hline \multirow[t]{3}{*}{ Cognitive domain } & Negative Ranks & 1 & 9 & 9 & & \\
\hline & Positive Ranks & 17 & 9.53 & 162 & -3.340 & 0.001 \\
\hline & Ties & 2 & & & & \\
\hline \multirow[t]{3}{*}{ Emotional domain } & Negative Ranks & 4 & 4.5 & 18 & & \\
\hline & Positive Ranks & 13 & 10.38 & 135 & -2.778 & 0.005 \\
\hline & Ties & 3 & & & & \\
\hline \multirow[t]{3}{*}{ Behavioral domain } & Negative Ranks & 6 & 6.17 & 37 & & \\
\hline & Positive Ranks & 13 & 9.90 & 99 & -1.608 & 0.108 \\
\hline & Ties & 3 & & & & \\
\hline \multirow[t]{3}{*}{ Total score } & Negative Ranks & 1 & 2 & 2 & & \\
\hline & Positive Ranks & 18 & 10.44 & 188 & -3.749 & 0.000 \\
\hline & Ties & 1 & & & & \\
\hline
\end{tabular}

The mean rank of the pretest total score of the experimental group students was 21.13, while the students in the control group had a pretest total score mean rank of 19.88. The close mean ranks of the groups' pretest climate change awareness total scores indicate that before the experimental application, the experimental and control groups had somewhat equal pretest levels. To examine the differences between the pretest \& posttest of the experimental group on the CCAS, A Wilcoxon Signed-rank test was conducted (Table 2). As noted in table 2, the Wilcoxon Signed-rank test indicated that the total posttest scores of the experimental group on the CCAS was higher than their pretest scores, $Z=-3.749, p<0.00$. Further, these findings had statistical significance.

Table (2): Results of Wilcoxon Signed-rank test to compare the pretest-posttest scores of the experimental group on the CCAS

\begin{tabular}{|c|c|c|c|c|c|c|c|}
\hline & \multicolumn{2}{|c|}{ Control group } & \multicolumn{3}{|c|}{ Experimental group } & \multirow[b]{2}{*}{$\mathrm{Z}$} & \multirow[b]{2}{*}{$\mathrm{P}$} \\
\hline & Mean Rank & $\begin{array}{l}\text { Sum of } \\
\text { Ranks }\end{array}$ & Mean Rank & $\begin{array}{l}\text { Sum of } \\
\text { Ranks }\end{array}$ & Df & & \\
\hline Cognitive domain & 20.03 & 400.5 & 20.98 & 419.5 & 38 &. .258 & .796 \\
\hline Emotional domain & 19.50 & 390 & 21.5 & 430 & 38 & -.546 & .585 \\
\hline Behavioral domain & 22.65 & 453 & 18.35 & 367 & 38 & -1.186 & .236 \\
\hline Total score & 19.88 & 397.5 & 21.13 & 422.5 & 38 & -.339 & .735 \\
\hline
\end{tabular}

The findings indicate that there were significant differences between the pretest and the posttest scores of the experimental group in the cognitive and emotional domain of the CCAS, and even on the total score. However, there were not significant differences between the means of students' scores on the behavioral domain.

Table (3): Results of Wilcoxon Signed-rank test to compare the pretest-posttest scores of the control group on the CCAS

\begin{tabular}{|c|c|c|c|c|c|c|}
\hline & & $\mathrm{N}$ & Mean Rank & Sum of Ranks & $\mathrm{Z}$ & $\mathrm{P}$ \\
\hline \multirow[t]{3}{*}{ Cognitive domain } & Negative Ranks & 1 & 1.5 & 1.5 & & \\
\hline & Positive Ranks & 10 & 6.45 & 64.5 & -2.817 & 0.005 \\
\hline & Ties & 9 & & & & \\
\hline \multirow[t]{3}{*}{ Emotional domain } & Negative Ranks & 5 & 5.3 & 26.5 & & \\
\hline & Positive Ranks & 5 & 5.7 & 28.5 & -0.102 & 0.919 \\
\hline & Ties & 10 & & & & \\
\hline \multirow[t]{3}{*}{ Behavioral domain } & Negative Ranks & 8 & 6.0 & 48 & & \\
\hline & Positive Ranks & 2 & 3.5 & 7 & -2.105 & 0.035 \\
\hline & Ties & 10 & & & & \\
\hline \multirow[t]{3}{*}{ Total score } & Negative Ranks & 5 & 4.5 & 22.5 & & \\
\hline & Positive Ranks & 5 & 6.5 & 32.5 & -0.517 & 0.605 \\
\hline & Ties & 10 & & & & \\
\hline
\end{tabular}


International Journal of Childhood, Counselling, \& Special Education (CCSE), Volume3, Issue1, Sept: 2021, pp.32-46

Another Wilcoxon Signed-rank test was conducted to examine the differences between the pretest \& posttest scores of the control group on the CCAS (Table 3). The results showed that there were significant differences between the pretest and the posttest scores of the control group in the cognitive and behavioral domain of the CCAS. However, there were not significant differences between the means of students' scores in the emotional domain and the total score.

In addition, $\mathrm{A}$ Mann-Whitney $\mathrm{U}$ test was conducted to examine the differences between the posttest scores of the control and experimental groups (Table 4). An examination of the results of the Mann Whitney $U$ test applied to the posttest Climate Change Awareness scores of the students in the experimental and control groups revealed a statistically significant difference at the level of $\mathrm{p}<0.05$ in all domains $(Z=-3.727, p=0.00)$ except the behavioral domain $(Z=-1.812, p=0.70>$ $0.05)$. The mean rank of the posttest total score of the experimental group students on the CCAS was 27.38, while the students in the control group had a posttest total score mean rank of 13.63 . The analyses show no significant difference between the mean ranks of the groups' pretest total scores on CCAS; however, an examination of the mean rank of their posttest total scores on CCAS demonstrates that the students in the experimental group had higher climate change awareness than those in the control group. This result indicates that the experimental group students attained more knowledge about climate change after the experimental application when compared to their peers in the control group.

Table (4): Results of Mann-Whitney U test to compare the groups' posttest scores on the CCAS

\begin{tabular}{lccccccc}
\hline & \multicolumn{2}{c}{ Control group } & \multicolumn{3}{c}{ Experimental group } \\
\hline & Mean Rank & Sum of Ranks & Mean Rank & Sum of Ranks & Df & Z & P \\
\hline Cognitive domain & 13.95 & 279 & 27.05 & 541 & 38 & -3.569 & 0.00 \\
Emotional domain & 13.98 & 279.5 & 27.03 & 540.5 & 38 & -3.554 & 0.00 \\
Behavioral domain & 17.18 & 343.5 & 23.83 & 476.5 & 38 & -1.812 & 0.70 \\
\hline Total score & 13.63 & 272.5 & 27.38 & 547.5 & 38 & -3.727 & 0.00 \\
\hline
\end{tabular}

To calculate the effect size of the enrichment unit on gifted students' climate change awareness, the following formula was used (Cohen, 1988):

$$
r=\frac{z}{\sqrt{N}}
$$

$\mathrm{N}=$ number of students in the control group + experimental group. Using this formula, the effect size of the enrichment unit on gifted students' climate change awareness was 0.56 on the cognitive domain, 0.56 on the emotional domain, 0.29 on the behavioral domain, and 0.59 on the total score, which represents the "medium" effect size of the intervention on gifted students' climate change awareness (Cohen, 1988).

To prove the second hypothesis of the study, the Mann-Whitney U test was used to examine the equivalency of the pretest scores on BSPSA between the experimental and control group (Table 5).

Table (5): Results of Mann-Whitney $U$ test to compare the groups' pretest scores on the BSPSA

\begin{tabular}{lccccccc}
\hline \multicolumn{2}{c}{ control group } & \multicolumn{2}{c}{ Experimental group } \\
\hline & Mean Rank & Sum of Ranks & Mean Rank & Sum of Ranks & Df & Z & P \\
\hline Observation & 22.45 & 449 & 18.55 & 371 & 38 & -1.063 & .288 \\
Communication & 19.80 & 396 & 21.20 & 424 & 38 & -.384 & .701 \\
Measurement & 19.20 & 384 & 21.80 & 436 & 38 & -.710 & .478 \\
Classification & 22.85 & 457 & 18.15 & 363 & 38 & -1.306 & .192 \\
\hline Total & 20.65 & 413 & 20.35 & 407 & 38 & -.081 & .935 \\
\hline
\end{tabular}

As indicated in table 5, the control and experimental pretest scores on the BSPSA were not statistically different $(\mathrm{p}>$
0.05). The Mean Rank of the pretest total score of the experimental group students on the BSPSA was 20.35, while the 
International Journal of Childhood, Counselling, \& Special Education (CCSE), Volume3, Issue1, Sept: 2021, pp.32-46

students in the control group had a pretest total score mean rank of 20.65. The close mean ranks of the groups' pretest climate change awareness scores indicate that before the experimental application, the experimental and control groups had somewhat equal basic science skills levels.
After applying the enrichment unit, A Wilcoxon Signed-rank test was conducted to measure the differences between the pretest \& posttest of the experimental group on the BSPSA (Table 6).

Table (6): Results of Wilcoxon Signed-rank test to compare the pretest-posttest scores of the experimental group on the BSPSA

\begin{tabular}{|c|c|c|c|c|c|c|}
\hline & & $\mathrm{N}$ & Mean Rank & Sum of Ranks & $\mathrm{Z}$ & $\mathrm{P}$ \\
\hline \multirow[t]{3}{*}{ Observation } & Negative Ranks & 0 & 0 & 0 & & \\
\hline & Positive Ranks & 19 & 190 & 10 & -3.831 & 0.00 \\
\hline & Ties & 1 & & & & \\
\hline \multirow[t]{3}{*}{ Communication } & Negative Ranks & 1 & 0 & 0 & & \\
\hline & Positive Ranks & 17 & 10 & 190 & -3.831 & 0.00 \\
\hline & Ties & 2 & & & & \\
\hline \multirow[t]{3}{*}{ Measurement } & Negative Ranks & 0 & 0 & 0 & & \\
\hline & Positive Ranks & 19 & 10 & 190 & -3.831 & 0.00 \\
\hline & Ties & 1 & & & & \\
\hline \multirow[t]{3}{*}{ Classification } & Negative Ranks & 0 & 0 & 0 & & \\
\hline & Positive Ranks & 16 & 8.50 & 136 & -3.531 & 0.00 \\
\hline & Ties & 4 & & & & \\
\hline \multirow[t]{3}{*}{ Total score } & Negative Ranks & 0 & 0 & 0 & & \\
\hline & Positive Ranks & 19 & 10 & 190 & -3.829 & 0.00 \\
\hline & Ties & 1 & & & & \\
\hline
\end{tabular}

As shown in table 6 , the results of the Wilcoxon test indicate that the differences between the pretest \& posttest of the experimental group on the Basic Science Process Skills Activities were statistically significant and the posttest scores of the experimental group on the BSPSA were higher than their pretest scores $(\mathrm{Z}=-3.829$, $\mathrm{p}<0.00$ ). A Wilcoxon Signed-rank test was also conducted for the control group to examine the differences between the pretest \& posttest scores on the BSPSA (Table 7).

Table (7): Results of Wilcoxon Signed-rank test to compare the pretest-posttest scores of the control group on the BSPSA

\begin{tabular}{|c|c|c|c|c|c|c|c|}
\hline & & & $\mathrm{N}$ & Mean Rank & Sum of Ranks & $\mathrm{z}$ & $\mathrm{P}$ \\
\hline \multirow[t]{3}{*}{ Observation } & Negative Ranks & & 6 & 5 & 30 & & \\
\hline & Positive Ranks & & 3 & 5 & 15 & 0.905 & 0.365 \\
\hline & Ties & 1 & 1 & & & & \\
\hline \multirow[t]{3}{*}{ Communication } & Negative Ranks & & 5 & 3.7 & 18.50 & & \\
\hline & Positive Ranks & & 4 & 6.63 & 26.50 & . & 0.631 \\
\hline & Ties & & 1 & & & & \\
\hline \multirow[t]{3}{*}{ Measurement } & Negative Ranks & & 2 & 5 & 10 & & \\
\hline & Positive Ranks & & 8 & 5.63 & 45 & & 0.72 \\
\hline & Ties & 0 & 1 & & & & \\
\hline \multirow[t]{3}{*}{ Classification } & Negative Ranks & & 5 & 6.10 & 30.50 & & \\
\hline & Positive Ranks & & 6 & 5.92 & 35.50 & , & 0.821 \\
\hline & & & 9 & & & 0.226 & \\
\hline \multirow[t]{3}{*}{ Total score } & Negative Ranks & & 2 & 6.25 & 12.50 & & \\
\hline & Positive Ranks & & 7 & 4.64 & 32.50 & . & 0.235 \\
\hline & Ties & & 1 & & & 1.188 & \\
\hline
\end{tabular}

As presented in table 7 , the results of Wilcoxon test indicated that there were no statistically significant differences between the pretest and posttest score of the control 
International Journal of Childhood, Counselling, \& Special Education (CCSE), Volume3, Issue1, Sept: 2021, pp.32-46

group on the BSPSA $(Z=-1,188, \mathrm{p}>$ 0.235).

Table (8): Results of Mann-Whitney U test to compare the groups' posttest scores on the BSPSA

\begin{tabular}{lccccccc}
\hline \multicolumn{7}{c}{ Control group } & \multicolumn{2}{c}{ Experimental group } \\
\hline & Mean Rank & $\begin{array}{c}\text { Sum of } \\
\text { Ranks }\end{array}$ & $\begin{array}{c}\text { Mean } \\
\text { Rank }\end{array}$ & $\begin{array}{c}\text { Sum of } \\
\text { Ranks }\end{array}$ & df & Z & P \\
\hline Observation & 11.38 & 227.5 & 29.63 & 592.5 & 38 & -4.96 & 0.00 \\
Communication & 13.45 & 269 & 27.55 & 551 & 38 & -3.836 & 0.00 \\
Measurement & 12.68 & 253.5 & 28.33 & 566.5 & 38 & -4.261 & 0.00 \\
Classification & 14.23 & 284.5 & 26.78 & 535.5 & 38 & -3.424 & 0.01 \\
\hline Total & 10.85 & 217 & 30.15 & 603 & 38 & -5.229 & 0.00 \\
\hline
\end{tabular}

A Mann-Whitney $U$ test was conducted (Table 8) to understand the differences between the posttest scores of the control and experimental groups. In an examination of the findings, table 8 shows that the results of the Mann-Whitney $U$ test applied to the posttest score on the BSPSA of the students in the experimental and control groups revealed a statistically significant difference at the level of $\mathrm{p}<$ 0.05 , which indicates that the experimental group students acquired more basic science process skills after the experimental application when compared to their peers in the control group $(Z=-5.229, p=0.00)$. The mean rank of the posttest total score of the experimental group students on the BSPSA was 30.15, while the students in the control group had a posttest total score mean rank of 10.85 . The analysis showed no significant difference between the mean ranks of the groups' pretest total scores on BSPSA; however, an examination of the mean rank of their posttest total scores on BSPSA demonstrates that the students in the experimental group had higher basic science process skills than those in the control group. This result indicates that the experimental group students acquired more basic science process skills after the experimental application when compared to their peers in the control group.

The effect size of the intervention on gifted students' basic science process skills was calculated using the formula mentioned previously, and the results indicate that the effect size of the unit on gifted students' observation skill is 0.78 , 0.61 on their communication skills, 0.67 on their measurement skills, 0.54 on their classification skills, and 0.82 on the total score, which shows the "large" size effect of the unit on gifted students' basic science process skills (Cohen, 1988).

\section{Discussion}

In this examination of the effects of an enrichment unit on gifted students' climate change awareness $\&$ basic science process skills, the research revealed several key understandings. First, there is no significant difference between the experimental and control pretest scores on CCAS and BSPSA at the 0.05 confidence level.

The first hypothesis was supported, that offering a climate change-themed enrichment unit to the curriculum of 6th grade females would enhance climate change awareness, The experimental group produced higher scores on the CCAS than controls. While pre- and post-test scores indicated both groups had increased climate change awareness, the experimental group scores were significantly higher than those for the controls.

As for controls, a significant rise from pre- to post-test in the cognitive and behavioral domains was observed, but not so in either the emotional domain or in the total score. Based on direct observation, control students had requested more information about climate change from 
their science teacher following the pre-test, and this is speculated to account for the cognitive and behavioral rise in scores. These results are consistent with findings by Mani, Banerjee, Pant, Godura, and Porwal (2011); Harker-schuch and BuggeHenriksen, (2013); and dewaters, Andersen, Calderwood, and Powers (2014) in their studies examining the effect of teaching climate change topics on students' climate change awareness.

Throughout the application process, it was observed that many students had misconceptions regarding the causes and consequences of climate change, and this result is consistent with Wachholz, Artz, and Chene's (2012) findings that many college students have misconceptions about the basic causes and consequences of climate change. Considering this study's findings, the researchers determined that the enrichment unit had an effect on gifted students' climate change awareness. The results of the current research and of these studies seem to support one another.

Based on the findings of the current study, the researchers suggest that climate change topics should be integrated in different schools' curricula (in the arts, language, social studies, science, etc.). This approach has the potential to spread climate change literacy and may lead to a reduction in some of the human activities that have been accelerating climate change.

The second hypothesis was confirmed, that offering a climate change-themed enrichment unit to 6 th grade female gifted students would affects their basic science process skills. Results showed a statistically significant difference at $\mathrm{p}<0.05$ between the experimental and control groups on development of observation, communication, measurement, and classification activities (BSPSA scale).

And whereas the control group showed no pre- to post-test differences, the experimental group BSPSA post-test scores were significantly higher than pre-test scores. We believe these differences were due to the nature of the enrichment unit in which students were asked to utilize their science process skills to respond to different activities and experiments in the unit. There were no statistically significant differences for the control group.

These results prove the above hypothesis. The literature also supports these findings. Aktamis and Ergin (2008), for example, propose that scientific process skills education helps to improve elementary students' scientific creativity, science attitudes, and academic achievements. In a study by Abu Lebda (2009), the researcher found that teaching young learners using the discovery mode helps in improving their science process skills more than traditional teaching methods. Similarly, Almaymooni (2014) postulates that all primary students should be involved in activities that require utilizing these basic science skills. At the end of this study, it was revealed that deductive activities, experiments, and learning by doing helped to improve gifted students' basic science process skills. Thus, educators need to consider this when planning for young learners' science activities.

For future research, we recommend that this unit be applied to a larger, randomized sample. Finally, it may be useful to conduct similar research on the effects of the enrichment unit on gifted students' creative problem-solving skills. Furthermore, the researcher proposes conducting more studies about gifted children and climate change education, especially for primary schools.

\section{References}

Abdeen, S., \& Ewies, M. (2019). The effect of creative acceleration strategy on creative thinking abilities of talented students in Saudi Arabia. Jurnal Pendidikan Bitara UPSI, 12: 21. 27. 
Abdeen, S. (2014). Theory Concurrent thinking. Life science journals, 11(12).

Abo Lebda, R. (2009). The effectiveness of the discovery mode on science process skills acquisition among $8^{\text {th }}$ graders (Master's thesis). Available from Dar Almanthooma Dissertation and Theses database.

Akinoglu, O., \& Tandogan. R. (2007). The effects of problem-based active learning in science education on students' academic achievement, attitude, and concept learning. Eurasia Journal of Mathematics, Science $\mathcal{E}$ Technology Education, 3(1): 71-81. https://doi.org/10.12973/ejmste/75375

Aktamis, H., \& Ergin, O. (2008). The effect of scientific process skills education on students' scientific creativity, science attitudes and academic achievements. Asia- Pacific Forum on Science Learning and Teaching, 9(1): 1-21. Retrieved from

http://www.ied.edu.hk/apfslt/download/v9_issue 1 files/aktamis.pdf

Aljasim, F. (2001). The school's role in identifying and raising the gifted students in the state of Bahrain. Paper presented at the scientific and cultural festival \& the second gifted meeting, Meridian Hotel, State of Kuwait.

Aljughaiman, A. (2017). The Comprehensive guide to create and implement gifted people's programs. UAE: Obeikan.

Almaymooni, S. (2014). The effect of a unit based on Parallel Curriculum on developing science skills and creative productivity among Kuwaiti $4^{\text {th }}$ graders (Unpublished Master thesis). Arabian Gulf University, the Kingdom of Bahrain.

Aydogdu, B. (2015). Examining preservice science teachers' skills of formulating hypotheses and identifying variables. AsiaPacific Forum on Science Learning and Teaching, 16 (1): 1-38. Retrieved from https://www.eduhk.hk/apfslt/download/v16 issu e1 files/aydogdu.pdf

Bainbridge, C. (2018). When Schools Don't Meet Your Gifted Child's Needs. Retrieved from https://www.verywellfamily.com/why-your-childneeds-an-appropriate-academic-setting-1449295
Beach, R., Share, J., \& Webb, A. (2017). Teaching climate change to adolescents (1st ed.). New York: Routledge.

Clark, B. (2007). Growing up gifted: developing the potential of children at home and at school (7th ed.). London: Pearson Education.

Cohen, J. (1988). Statistical power analysis for the behavioral sciences (2nd ed.). Hillsdale, NJ: Lawrence Earlbaum Associates.

Coronado, R. (2016). Correlations between science process skills and test taking abilities among grade VIII students input in designing test matrix. (Master's Thesis). Laguna State Polytechnic University, San Pablo City Campus.

Coyle, K. (2005). Environmental literacy in America: What ten years of NEETF/Roper Research studies say about environmental literacy in the U.S. National Environmental Education and Training Foundation. Retrieved from http://tinyurl.com/jk3jfkj.

DeWaters, J., Andersen, C., Calderwood, A., $\&$ Powers, S. (2014). Improving climate literacy with project-based modules rich in educational rigor and relevance. Journal Of Geoscience Education, 62(3): $\quad$ 469-484. http://dx.doi.org/10.5408/13-056.1

Johnsen, S., \& Corn, A. (2001). Screening assessment for gifted elementary and middle school students ( $2^{\text {nd }}$ ed.). Waco, TX: Prufrock Press.

Harker-Schuch, I., \& Bugge-Henriksen, C. (2013). Opinions and knowledge about climate change science in high school students. AMBIO, 42(6): $\quad$ 755-766. http://dx.doi.org/10.1007/s13280-013-0388-4

Harlen, W. (1999). Purposes and procedures for assessing science process skills. Assessment in Education, 6(1), http://dx.doi.org/10.1080/09695949993044

Hestness, E., McDonald, C., Breslyn, W., McGinnis, R., \& Mouza, C. (2014). Science teacher professional development in climate change education informed by the next generation of science standards. Journal of Geoscience Education, 62(3): 319-329. https://www.tandfonline.com/doi/abs/10.5408/1 3-049.1 
Intergovernmental Panel on Climate Change (IPCC). (2013). Climate change 2013: The physical science basis. Contribution of working group I to the fifth assessment report of the Intergovernmental Panel on Climate Change. United Kingdom: Cambridge University Press.

Intergovernmental Panel on Climate Change (IPCC). (2016). Fifth assessment report. New York: Cambridge University Press. Retrieved from http://ipcc.ch

IPCC (2014). Summary for policymakers: climate change 2014: impacts, adaptation, and vulnerability. IPCC, Geneva, Switzerland. Retrieved from www.ipcc.ch

Jarwan, F. (2002). Ways of identifying gifted students and nurturing them. Oman: Dar AlFekr Press.

Karamustafaoglu, S. (2011). Improving the science process skills ability of science student teachers using I diagrams. Eurasian Journal of Chemical Education. 3(1): 26-38. https://doi.org/10.51724/ijpce.v3i1.99

Mani, S., Banerjee, D., Pant, D., Godura, S., \& Porwal, P. (2011). Educating for a healthy environment. International Forum of Teaching and Studies, 7(2): 56-62.

Maranan, V. (2017). Basic process skills and attitude toward science: input to an enhanced students' cognitive performance. (Unpublished Master's Thesis). Laguna State Polytechnic University, San Pablo City Laguna.

Miles, E. (2010). In-service elementary teachers' familiarity, interest, conceptual knowledge, and performance in science process skills. (Master's thesis). Southern Illinois University Carbondale, USA. Available from ProQuest, UMI Dissertations publishing, (UMI No. 1482656).

Ministry of Education in Bahrain. (2012). A document of raising gifted and talented students' program in government schools. The Kingdom of Bahrain.

National Research Council (NRC). (2013). The next generational science standards. Washington, DC: National Academies Press.
Ostlund, K. \& Mercier, S. (2012). Science assessment activities for primary: Level 1. California: S \& K Association.

Padilla, M. (1990). The science process skills Research Matters-to the science teacher. National Association for Research in Science Teaching. Retrieved from https://www.narst.org/publications/research/skill. $\underline{\mathrm{cfm}}$

Panoy, B. (2013). Differentiated strategy in teaching and skills development of pupils in elementary science. (Unpublished master thesis). Laguna State Polytechnic University, San Pablo City Laguna.

Pirie, B. (1997). Reshaping high school English. Urbana, IL: National Council of Teachers of English.

Rakow, S. (2011). Educating gifted students in middle school (2nd ed.). Waco, TX: Prufrock Press.

Renzuli, J., Smith, L., White, A., Cahhahan, C., Hartman, R., \& Westberg, K. (2002). Scales for rating the behavior characteristics of superior students (Rev.ed.). Mansfield Center, CT: Creative Learning Press.

Renzulli, J. (2005). Three ring conceptions of giftedness. In R. J. Sternberg \& J. E. Davidson (Eds.), Conceptions of giftedness (2nd ed., pp. 246-279).

https://doi.org/10.1017/cbo9780511610455.015

Rideout, V., Luricella, A., \& Wartella, E. (2011). Children, media and race: Media use among white, black, Hispanic, and Asian American children. Center on Media and Human Development School of Communication. Chicago: Northwestern University.

Rillero, P. (1998). Process skills and content knowledge. Science Activities: Classroom Projects and Curriculum Ideas, 35 (3): 3-4, DOI:10.1080/00368129809600910

Rimm, S., Siegle, D., \& Davis, G. (2017). Education of the gifted and talented (7th ed.). London: Pearson.

Shepardson, D., Roychoudhury, A., \& Hirsch, A. (2017). Teaching and learning about climate change (1st ed.). New York: Routledge. 
International Journal of Childhood, Counselling, \& Special Education (CCSE), Volume3, Issue1, Sept: 2021, pp.32-46

Skamp, K. (1988). Teaching primary science constructively. (3rd ed). Australia: Cengage Learning Australia Pty Limited.

Smith, L., Bock, M., Farrow, K., \& Gerardy, N. (2004). A Guide for Developing Gifted Curriculum Documents. Colombia, MO. Retrieved from https://dese.mo.gov/divimprove/gifted/resou rces/curriculumguide.pdf

Stankorb, S. (2016). Climate fiction or "cli-fi" is the hottest new literary genre. The Daily Good. Retrieved from www.good.is/articles/climatefiction-cli-fi-genre.

Smith, P., \& Howe, N. (2015). Climate change as social drama: Global warming in the public sphere. New York: Cambridge University Press.

Turner, R. (2015). Teaching for ecojustice: Curriculum and lessons for secondary and college classrooms. New York: Routledge.

U.S. Department of Education. (1993). National excellence: A case for developing America's talent. Washington, DC.

UNESCO (2013). Climate change education for sustainable development at UNESCO. Retrieved from http://en.unesco.org/themes/educationsustainable-development/cce

VanTassel-Baska, J. (1994). Comprehensive Curriculum for Gifted Learners ( $2^{\text {nd }}$ ed.). United States of America: Allyn and Bacon.

Wachholz, S., Artz, N., \& Chene, D. (2014). Warming to the idea: university students' knowledge and attitudes about climate change. International Journal of Sustainability in Higher Education, $\quad 15(2)$ : $128-141$. http://dx.doi.org/10.1108/ijshe-03-2012-0025

William, F. (1980). Creativity assessment packet. Buffalo, NY: DOK.

Wu, J., \& Lee, J. (2015). Climate change games as tools for education and engagement. Nature Climate Change, 5, 413-418. Retrieved from www.nature.com/natureclimatechange,

Zeidan, A., \& Jayosi, M. (2015). Science process skills and attitudes toward science among Palestinian secondary school students. World Journal of Education, 5(1): 13-24. http://dx.doi.org/10.5430/wje.v5n1p13 